Paweł Jabłoński', Przemysław Kaczmarek ${ }^{2}$ University of Wrocław

\title{
On an Interpreter's Game with the Legal Text and Extratextual Factors in the Derivative Concept of Legal Interpretation ${ }^{3}$
}

It is noteworthy that a text without any specific interpretation is of interest to calligraphers or printers only. An inscription is not a sign unless it is endowed with sense.

Zygmunt Ziembiński ${ }^{4}$

Meaning is actually a game between the interpreter and the broadly understood text.

Maciej Zieliński, Marek Zirk-Sadowski ${ }^{5}$

\section{Introduction}

The aim of this article is to examine the derivative concept of legal interpretation (Polish: derywacyjna koncepcja wyktadni prawa) from the perspective of the structure, as developed by us, of the limits of juristic power ${ }^{6}$. This text is a continuation of a project we have taken up in another work, where the set structure of boundaries was examined in relation to sociological and socio-legal theories ${ }^{7}$. The relatively narrow framework dictated by the form of an article calls for setting some constraints. Firstly, the presentation of the structure of the limits of juristic power is reduced to the bare minimum, since it has been widely discussed by us in another work ${ }^{8}$. Secondly, our aim is not to conduct

ORCID number: 0000-0002-9562-4419. E-mail: pawel.jablonski@uwr.edu.pl

ORCID number: 0000-0002-3436-4043. E-mail: przemysław.kaczmarek@uwr.edu.pl

When we were sending this paper to the Editorial Office of "Archiwum Filozofii Prawa i Filozofii Społecznej", we hoped that we would be able to discuss its contents with the originator of the concept discussed by us, i.e., Professor Maciej Zieliński (who passed away recently). Many times in the past we found that Professor Zieliński always contributed his valuable and productive comments. We are certain that it would have been no different this time.

4 Z. Ziembiński, Tworzenie a stanowienie i stosowanie prawa [Eng. Lawmaking, Legislation and Application of Law], "Ruch Prawniczy, Ekonomiczny i Socjologiczny" 1993/4, pp. 44-45.

5 M. Zieliński, M. Zirk-Sadowski, Klaryfikacyjność i derywacyjność w integrowaniu polskich teorii wyktadni prawa [Eng. The Clarifying and the Derivative Aspect in the Integration of Polish Theories of Legal Interpretation], "Ruch Prawniczy, Ekonomiczny i Socjologiczny” 2011/2, p. 110.

6 We would like to thank Professor Agnieszka Choduń and Professor Włodzimierz Gromski for reading this text and for their in-depth and valuable comments.

7 P. Jabłoński, P. Kaczmarek, The Limits of Juristic Power from the Perspective of the Polish Sociological Tradition, Berlin 2019.

8 P. Jabłoński, P. Kaczmarek, The Limits..., pp. 13-21. 
a comprehensive or exhaustive analysis of the derivative model; instead, we would like to identify a few directions and questions which we consider interesting.

The derivative concept of legal interpretation ${ }^{9}$ remains an interesting and vital point of reference for the problem of the limits of juristic power for a number of reasons. Firstly, at this point in time, it seems to be the most prominent Polish theory of interpreting law. Not only it is creatively invoked by successive domestic researchers such as Leszek Leszczyński, Ryszard Sarkowicz, Marcin Matczak, Agnieszka Choduń, Andżelika Godek or Olgierd Bogucki, who either expand or adapt it to their own constructs, but it also constitutes the core axis of the integrated theory of interpretation.

Secondly, it is an open concept. Its openness finds reflection in the inclusion in this construct of adaptively modified elements of other theories of legal interpretation, such as the clarificative concept (Polish: klaryfikacyjna teoria wyktadni) or the theory of levels of interpretation of legal text (Polish: teoria poziomowej interpretacji tekstu prawnego). A very promising aspect of the above-mentioned openness of this derivative model is its slant, noticeable in recent years, towards the hermeneutical tradition of thinking and the recognition that it can be integrated with this model with no intrusion upon its coherence ${ }^{10}$. It is particularly interesting from the perspective of the objectives outlined in this paper because, as the key creator of the derivative concept Maciej Zieliński ${ }^{11}$ has also admitted, hermeneutics accepts that the interpreter has a significant influence on the shape of interpretation, yet it is by no means an arbitrary process. Interpretation is thus a kind of game between the text and the differently understood interpreter ${ }^{12}$. The game itself and the relationship between the derivative model and the hermeneutical approach to interpretation are presented in a monographic publication on this model by the aforementioned A. Chodun ${ }^{13}$. A remarkable proof of the open character of the derivative theory also lies in its applicability to new socio-legal challenges, including the multicentricity of the contemporary law and the consequent interpenetration of Poland's legal system with the law of the European Union ${ }^{14}$.

Thirdly, on account of the highly developed, though at the same time normative quality of this concept, it can be viewed as a kind of a complex answer to a question

\footnotetext{
9 In this paper, we use the terms "theory", "concept" and "model" interchangeably. Although we realise the inherent simplification involved, however, it does not seem to be of any relevance to the issues discussed here. As regards the signalled differences, see: R. Sarkowicz, Uwagi o wspótczesnej interpretacji prawniczej [Eng. Observations on Contemporary Legal Interpretation], in: S. Wronkowska (ed.), Polska kultura prawna a proces integracji europejskiej [Eng. Polish Legal Culture and the European Integration Process], Kraków 2005, pp. 16-19.

10 See: M. Zieliński, M. Zirk-Sadowski, Klaryfikacyjność..., pp. 100-101.

11 M. Zieliński, Wyktadnia prawa. Zasady - reguty - wskazówki [Eng. Legal Interpretation: Principles, Rules, Recommendations], Warszawa 2017, p. 85. This book is the primary point of reference for us in presenting the derivative concept of interpretation of law.

12 The interpreter can, in our view, be deemed to be 1) a specific jurist, 2) a legal interpretative community, as well as 3) a legal and political community.

13 A. Choduń, Aspekty językowe derywacyjnej koncepcji wyktadni prawa [Eng. The Linguistic Aspects in Derivative Conception of Legal Interpretation], Szczecin 2018, p. 33.

14 See: A. Bator, O adekwatności założeń derywacyjnej koncepcji wyktadni do badań nad interpretacja prawa Unii Europejskiej [Eng. On the Adequacy of the Assumptions of the Derivative Concept of Interpretation to Research on the Interpretation of European Union Law], "Studia Prawa Publicznego" 2015/2, p. 11-34; A. Godek, Czy koniec teorii wyktadni prawa? Kilka uwag o możliwych rozwinięciach derywacyjnej koncepcji wyktadni Macieja Zielińskiego na wyktadnię prawa $w$ sferze postakcesyjnej z wewnętrznej perspektywy interpretacyjnej [Eng. Is it the End of the Theory of Legal Interpretation? Few Remarks on the Possible Expansion of Maciej Zielinski's Derivative Concept of Interpretation of Law into Interpretation of Law in the Post-Accession Phase from an Internal Interpretation Perspective], in: P. Jabłoński (ed.), Czy koniec teorii prawa? Z zagadnien teorii i filozofii prawa [Eng. Is it the End of the Theory of Law? Some Issues of Theory and Philosophy of Law], Wrocław 2011.
} 
of what should a lawyer be constrained by in the process of interpretation. As Tomasz Pietrzykowski has rightly noted:

The derivative approach to interpretation may be regarded not only as an approach outlining the right way to interpret the law, but also as a comprehensive and intellectually sophisticated methodological concept of the legal science. Based on the assumption that the lawmaker is rational, it creates a certain coherent overall vision of the proper way to act for a lawyer who strives to establish the content of the applicable legal norms ${ }^{15}$.

Fourthly, Zieliński's approach to interpretation is one of the most unique and reflectively developed constructs of the Polish theory of law. It does at the same time provide an elaborate conceptual grid which is appropriate enough, as noted by Matczak ${ }^{16}$, to capture the discursive nature of legal directives, which seems to be a rare phenomenon, also in the world of global jurisprudence.

\section{The structure of limits of juristic power}

Having outlined the reasons why we consider the derivative concept of interpretation an important point of reference when contemplating the limits of juristic power, let us proceed to mention a few words about the limits themselves. We assume that they have the following structure: 1) politico-legal culture; 2) legal text; 3) juristic culture; and 4) individual axiological approach. By politico-legal culture we mean the political morality of the given society which provides the fundamental axiological framework. Although it is largely enshrined in the text of the constitution, however, extricating it as a separate limit seems essential. One of the underlying reasons is the need to avoid the acceptance of the assertion, at odds with the contemporary understanding of the law, that the lawmaker may, subject to the appropriate procedures (or, more precisely, that the lawmaker might, were it not for international and supranational law), sculpt the legal order in an absolutely arbitrary manner, and in doing so, for example, amend the constitution so that human dignity becomes an attribute that is individually awarded and withdrawn by a special unit of public administration. As regards a legal text, we identify the text with a legal regulation. We define the juristic culture, in turn, to mean a combination of expertise and skills required for due exercise of law, which stem from the social division of labour and are rooted in the tradition of jurisprudence. Lastly, the individual axiological approach is the factor associated with the personality of the interpreter, his or her ethical judgements and aesthetic values associated with taste. This factor can demonstrate itself either more strongly, where it means allowing the personal axiological preferences of the interpreter to come to the fore or, in a weaker way, where it produces merely individual attempts at recognizing the debatable, from the point of view of its interpretation, content of a legal text as well as the requirements of politico-legal and juristic cultures.

15 T. Pietrzykowski, Naturalizm i granice nauk prawnych. Esej z metodologii prawoznawstwa [Eng. Naturalism and Limits of Legal Sciences: An Essay on the Methodology of Jurisprudence], Warszawa 2017, p. 90.

16 See: M. Matczak, Dwupoziomowość języka prawnego w derywacyjnej koncepcji wyktadni i jej znaczenie dla wspótczesnych sporów w anglosaskiej interpretacji prawniczej [Eng. Two Strata of Legal Language in the Derivative Interpretation Concept and its Significance for the Contemporary Disputes in the Anglo-Saxon Legal Interpretation], in: A. Choduń, S. Czepita (eds.), W poszukiwaniu dobra wspólnego. Księga jubileuszowa Profesora Macieja Zielińskiego [Eng. In Quest for the Common Good: Jubilee Book of Professor Maciej Zielinski], Szczecin 2010, pp. 129-140; M. Matczak, Imperium tekstu. Prawo jako postulowanie i urzeczywistnianie świata możliwego [Eng. The Text Empire: Law as Postulating and Realising of the World of the Possible], Warszawa 2019, pp. 67-68, 123. 
We have also assumed that there are two relationships between the limits thus drawn, i.e., that of complementation (Polish: dopetnienie) and adjustment (Polish: korekta) ${ }^{17}$. The former relationship entails that each subsequent limit exists, as a rule, within the framework of the former limits. In other words, each earlier limit establishes a certain initial factuality which determines the conditions and room for the entry of the later limit. The relationship of adjustment, on the other hand, means that in exceptional cases a subsequent limit may provide arguments to break out of the framework set by the earlier limit, and the condition for such a break-out is to stay within the other two limits. For example, the juristic culture comprises a contra legem argument, while a lawyer, if he or she has solid arguments, may attempt to override some of the interpreting practices or, more broadly, modes of action prevailing in jurisprudence and legal scholars writings. According to the pattern outlined above, the juristic culture that overrides the text should find backing in the politico-legal culture and the sense of responsibility of individual jurists. A lawyer who overturns a way of action accepted by juristic culture should rely on additional, strong arguments referring to the values of the politico-legal culture and the wording of a legal text.

Actually, the described game between these limits applies only to circumstances where the law is held in high regard, that is to say basically all this refers to the reality of a country ruled by law. It is clear to us that in authoritarian systems with a superficial law, the described limits are, perhaps with the exception of the legal text, destroyed and the text itself lacks the support of the remaining elements of the structure and thus ceases to have any meaning ${ }^{18}$.

At a first glance, it may seem that under the derivative concept of interpretation, the legal text determines the totality of lawyer's interpretative actions, which would mean that already at the starting point there is a contradiction between the structure outlined above and the derivative model. This impression is further magnified by the following assumption of the concept: "the directives of interpretation are set not by anyone's interpretative behaviour, but by the actual properties of the legal texts which, if correctly recognized, impose a certain, and no other, way of interpreting" ${ }^{\prime 19}$. However, this unilateral anchor to the properties of the text was later modified in favour of the approach that the model interpretation should draw from both features of the legal texts as well as from the legacy of juristic culture, including the established modes of action of supreme judicial bodies ${ }^{20}$. Regardless of this modification, we venture to demonstrate that the mode of conduct recommended by the derivative concept of interpretation leaves room for what serves as extratextual limits in the structure presented above. Two complementary tasks must be accomplished for this purpose. On the one hand, we will

17 In this context, we can probably refer to a remote inspiration derived from very interesting Tomasz Gizbert-Studnicki's substantive and terminological findings on purpose-oriented interpretation. See: T. Gizbert-Studnicki, Wyktadnia celowościowa [Eng. Purpose-Oriented Interpretation], "Studia Prawnicze" 1985/3-4, particularly pp. 61-64.

18 See: A. Podgórecki, Mega-sociology, Warszawa 2016, pp. 67-69; L. Leszczyński, Wyktadnia prawa - model ogólny [Eng. Legal Interpretation: General Model], in: A. Kalisz, L. Leszczyński, B. Liżewski, Wyktadnia prawa. Model ogólny a perspektywa Europejskiej Konwencji Praw Człowieka i prawa Unii Europejskiej [Eng. Legal Interpretation: The General Model and the Perspective of the European Convention on Human Rights and European Union Law], Lublin 2011, particularly pp. 60-66.

19 M. Zieliński, Derywacyjna koncepcja wyktadni jako koncepcja zintegrowana [Eng. Derivative Concept of Legal Interpretation as an Integrated Concept], "Ruch Prawniczy, Ekonomiczny i Socjologiczny" 2006/3, p. 95.

20 M. Zieliński, Wyktadnia..., pp. 199, 217, 220. See also: M. Zieliński, O. Bogucki, A. Choduń, S. Czepita, B. Kanarek, A. Municzewski, Zintegrowanie polskich koncepcji wyktadni prawa [Eng. Integration of Polish Concepts of Legal Interpretation], "Ruch Prawniczy, Ekonomiczny i Socjologiczny" 2009/4, p. 24. 
make an attempt to "weaken" the text, that is to bring to the fore the argument that, based on the derivative theory, one of those properties of texts that determine the mode of their interpreting is their inability to fully define the shape of its interpretation. On the other hand, we will strive to "strengthen" the remaining limits, i.e., highlight those few moments when they clearly come to light. However, it doing so, we are guided not so much by the derivative model in the attempt to modify it, but by a certain interpretative work conducted while moving around its theoretical structures.

\section{General characteristics of the derivative concept of legal interpretation}

The derivative concept of legal interpretation can be most generally described by reference to four basic assumptions. Firstly, although it originated from an analysis of properties of legal texts, as we have already mentioned, at present it draws both from these texts and from the well-established practice of professionals providing services in the field of law. Nonetheless, regardless of the concept's opening-up to solutions developed in practice, the distinction between a legal provision and a legal norm introduced by Ziembiński and related to the properties of legal texts, remains at its core ${ }^{21}$. This distinction, regarded as the foundation of the entire Poznan-Szczecin school of $\mathrm{law}^{22}$, sets a very interesting paradigm of thinking about law which fits well with the continental tradition ${ }^{23}$.

Secondly, it is assumed under the derivative concept that understanding of a legal text always requires interpretation, which is associated not only with the specific qualities of this text, but also with the recognition that law is a cultural object ${ }^{24}$.

The third assumption concerns the sequential nature of interpretation. Accordingly, interpretation follows sequential, yet partly intersecting phases (arrangement, reconstructive and perceptual phases), and each of the phases requires a certain chronology in the application of interpretative directives.

The fourth assumption concerns the application of the derivative concept. It is universalistic in a double sense ${ }^{25}: 1$ ) it can be presented both as a doctrinal and operative concept, at least in the sense that it is aimed at being applied in the practice of jurisprudence; 2) it can be applied to various fields of law and legal professions.

The derivative concept originated from certain findings made by Ziembiński, and further developed and expanded by Zieliński ${ }^{26}$. According to the latter of the two authors, two phases in the development of this concept can be distinguished ${ }^{27}$. The main feature of the first phase was individualization, and of the second, integration.

21 Z. Ziembiński, Przepis prawny i norma prawna [Eng. Legal Provision and Legal Norm], "Ruch Prawniczy, Ekonomiczny i Socjologiczny" 1960/1, pp. 105-122.

22 S. Czepita, S. Wronkowska, M. Zieliński, Zatożenia szkoty poznańsko-szczecińskiej w teorii prawa [Eng. Assumptions of the Poznań-Szczecin School in the Theory of Law], "Państwo i Prawo" 2013/2, p. 9.

23 See: L. Nowak, Zygmunta Ziembińskiego koncepcja interpretacji. Pewne komentarze, dopetnienia i aplikacje [Eng. Zygmunt Ziembiński's Concept of Interpretation: Some Comments, Additions and Applications], in: A. Klawitera, L. Nowak, P. Przybysz (eds.), Umyst a rzeczywistość [Eng. Mind and Reality], "Poznańskie Studia z Filozofii Humanistyki” 1999/5, pp. 424-425.

24 M. Zieliński, Wyznaczniki regut wyktadni prawa [Eng. Determinants of Legal Interpretation Rules], "Ruch Prawniczy, Ekonomiczny i Socjologiczny" 1998/3-4, p. 9ff.; M. Zieliński, Wyktadnia..., p. 57.

25 M. Zieliński, Wyktadnia..., p. 226-229.

26 See: M. Zieliński, Interpretacja jako proces dekodowania tekstu prawnego [Eng. Interpretation as the Process of Decoding a Legal Text], Poznań 1972; M. Zieliński, Wyktadnia..., p. 77.

27 M. Zieliński, Derywacyjna koncepcja..., p. 93. 
The phase of individualization which lasted until the mid-nineties of the twentieth century was the time of confrontation between the derivative and clarificative concepts of interpretation of law. The relationship between the two concepts became the subject of an analysis by Krzysztof Płeszka and Tomasz Gizbert-Studnicki in the study under the title Dwa ujęcia wyktadni prawa. Próba konfrontacji [Eng. Two Approaches to Interpretation of Law: Attempt at Confrontation ${ }^{28}$. In this paper, the two theorists from Kraków pointed to the basic similarities and differences between the derivative and clarificative concepts of interpretation of law. Although that paper seems to be the most frequently cited commentary on the derivative concept, it noteworthy that today the authors themselves acknowledge the need to verify their findings given the evolution of the derivative approach ${ }^{29}$.

As emphasized by Zieliński, a gradual easing of confrontational positions by supporters of the derivative and clarificative concepts of interpretation of law is observable since the second half of the nineties ${ }^{30}$. This process involves searching for common grounds of both these approaches to interpretation with the idea to integrate different ways of thinking about interpretation ${ }^{31}$. This was the intention behind the work under the title Klaryfikacyjność i derywacyjność w integrowaniu polskich teorii wyktadni prawa [Eng. Clarificative Approach and Derivativeness in Integrating Polish Theories of Interpretation of Law] by Zieliński and Zirk-Sadowski ${ }^{32}$.

It seems that besides the above-mentioned integrative direction of changes in the derivative concept, there is another important feature of its evolution that can be highlighted. Generally speaking, it is a sort of pragmatization, or simply a turnaround towards practice ${ }^{33}$. On the one hand, this theory itself has opened up to solutions developed by the jurisprudence, and on the other hand, it has reworked some of its elements so as to adapt to the realities, needs and requirements of application of law in practice. Example of such changes include easing of the requirements of unambiguity of a legal norm, the introduction of the "interpretational moment" (Polish: moment interpretacyjny) or the increased role of functional interpretation (Polish: wyktadnia funkcjonalna).

\section{Non-autonomous status of a legal text}

A key element of the derivative concept that weakens the meaning of the text is the underlying distinction between a legal provision and a legal norm ${ }^{34}$. This distinction entails that the meaning of a legal provision must be determined through interpretation,

28 K. Płeszka, T. Gizbert-Studnicki, Dwa ujęcia wyktadni prawa. Próba konfrontacji [Eng. Two Approaches to Legal Interpretation: An Attempt at Confrontation], “Zeszyty Naukowe Uniwersytetu Jagiellońskiego. Prace z Nauk Politycznych” 1984/20, p. $17 \mathrm{ff}$.

29 T. Gizbert-Studnicki, Rozkład ciężaru argumentacji w dyskursie interpretacyjnym [Eng. Distribution of the Burden of Argumentation in an Interpretative Discourse], in: J. Stelmach (ed.), Studia z filozofii prawa [Eng. Studies on the Philosophy of Law], Kraków 2003, p. 66; K. Płeszka, Wyktadnia rozszerzająca [Eng. Expansionary Interpretation], Warszawa 2010, p. 165ff. See also: M. Zieliński, Mitów w myśleniu o wyktadni prawa ciag dalszy [Eng. Some More Myths in Thinking on Legal Interpretation], in: A. Mróz, A. Niewiadomski, M. Pawelec (eds.), Prawo, język, media [Eng. Law, Language, Media], Warszawa 2011, pp. 120-121.

30 M. Zieliński, Derywacyjna koncepcja..., p. 93.

31 M. Zieliński, O. Bogucki, A. Choduń, S. Czepita, B. Kanarek, A. Municzewski, Zintegrowanie polskich...; M. Zieliński, M. Zirk-Sadowski, Klaryfikacyjność..., p. 99ff.

32 M. Zieliński, M. Zirk-Sadowski, Klaryfikacyjność..., passim.

33 This aspect was noted by: L. Leszczyński, Wyktadnia operatywna (podstawowe wtaściwości) [Eng. Operative Interpretation: Basic Features], "Państwo i Prawo" 2009/6, p. 18-20.

34 M. Zieliński, Wyktadnia..., p. 17. 
while the outcome of the interpretation process may lead to a result (norm of conduct) that is semiotically different from what was the object of interpretation ${ }^{35}$. Legal provisions are not themselves the law, but "building blocks" of law. Although they remain the key determinant of the content of applicable legal norms, they do not determine everything. They are just a starting point, rather than the result, in the "game of law". Thus, "normative acts and legal provisions are not the law; laws are decoded from legal provisions during the process of interpretation" 36 . According to this concept, "the linguistic content of legal provisions is an essential determinant of the content interpreted in the process of interpreting the norms, but it is by no means the only determinant" ${ }^{37}$. The key passage which is of interest from our perspective reads:

Hardly any theoretical school stresses equally strongly that the content of law, being a set of norms, is also determined by factors other than the wording of the legal provisions; the school precisely identifies these factors and describes the mode in which they influence them, and at the same time it proclaims that on account of the assumptions made in Poland's contemporary juristic culture, the objectives and other values which we rely on the process of interpretation, must be decoded primarily from the legal text ${ }^{38}$.

Therefore, determining how these "building blocks" of law are to be construed, i.e., establishing what exact provisions and in what exact wording need to be examined (the arrangement phase), what normative expressions need to be derived from them (the reconstructive phase) and, eventually, what norms need to be decoded from the latter (the perceptual phase) ${ }^{39}$ - all this is transpiring beyond the legal text itself, although in a close connection with it.

The non-autonomous status of a legal text (or, to be more precise, the non-autonomous meaning of a legal text) is noticeable not only when one applies systemic and functional rules of interpretation as well as those which are often referred to, after Jerzy Wróblewski, as second-degree rules (Polish: reguly drugiego stopnia) ${ }^{40}$, but also when the rules of linguistic interpretation are applied. Other than in exceptional circumstances that may for example concern legal definitions, the latter rules are not inbuilt in a legal text. Moreover, as Marek Safjan rightly highlights, the omnia sunt interpretanda principle associated with the derivative theory of legal interpretation "assumes a radical, even revolutionary change in the area of semantic interpretation" ${ }^{41}$. This change seems to correspond very well to the findings of the contemporary philosophy of language, according to which it is becoming increasingly difficult to talk of a "purely semantic meaning" or so because semantics itself is becoming more and more pragmatic. Although the analytical distinction between linguistic and extralinguistic (including systemic and functional) rules of interpretation, promoted under the derivative concept, does not reflect such a pragmatic semantics, yet the acceptance of the omnia sunt interpretanda principle with the option of adjusting the end-result derived with the use of linguistic rules, seems to largely meet this need.

M. Zieliński, Wyktadnia..., p. 77.

36 S. Czepita, S. Wronkowska, M. Zieliński, Zatożenia szkoty..., p. 10.

37 S. Czepita, S. Wronkowska, M. Zieliński, Zatożenia szkoty ..., p. 10.

38 S. Czepita, S. Wronkowska, M. Zieliński, Zatożenia szkoty..., p. 11.

39 M. Zieliński, Wyktadnia..., p. 281-302.

40 On the presence of second-degree rules in the derivative model see: T. Gizbert-Studnicki, Dyrektywy wyktadni drugiego stopnia [Eng. Second Degree Interpretation Directives], in: A. Choduń, S. Czepita (eds.), W poszukiwaniu..., p. 65.

${ }^{41}$ M. Safjan, Uniwersalizacja wyktadni prawa [Eng. Universalisation of Legal Interpretation], in: A. Choduń, S. Czepita (eds.), W poszukiwaniu..., p. 272. 
The significance of the non-autonomous status of a text is not limited to what is referred to as a complementary creative interpretation (Polish: wyktadnia uzupetniajaca-kreujaco) in the derivative concept of legal interpretation nor even to the complementary interpretation (Polish: wyktadnia uzupetniajaca) in general (and thus also complementary consequent (Polish: wyktadnia uzupetniajaca-konsekwencyjnie) $)^{42}$, but it plays an important role in the overall interpretation process. It should be noted, however, that the non-autonomous status of a legal text and the related need for the contribution of juristic culture and a given individual in the process of its interpretation is quite different from the law-making quality of this interpretation, which is limited in the context of the derivative concept to the aforementioned situation of complementary creative interpretation ${ }^{43}$. On this we read, inter alia, that: "[i]t should be accentuated with due firmness and emphasis that it is by no means justified to extend the conviction on the law-making quality of the complementary creative interpretation (sensu largo) to the other roles of interpretation" ${ }^{44}$.

Such recognition and accentuation of the boundary of lawmaking, i.e., the boundary of creative interpretation, seems somewhat problematic. One may risk an assertion that at this very moment, the derivative concept of legal interpretation divulges the process of attrition between various sources that bring this concept to life. These are, on the one hand, its positivist legal and naturalistic underlying assumptions (in the sense of ontological and epistemological objectivity or, in other words, in the sense of a sharp contrast between a subject and object of cognition) $)^{45}$, and on the other hand, the hermeneutical philosophical tradition which this concept increasingly sympathizes with. According to the hermeneutical approach, there are no grounds for the rigid separation between creative and reproductive moments in the process of interpretation. Instead, what matters here is whether the interpretation is right from the point of view of the tradition from which it is derived (in this case, the legacy of jurisprudence and the body of judgements), as well as the opportunities offered by the text and the practical problem it must solve.

Let us note that relying on the argument of lawmaker's rationality, which is made to support the thus established boundary of lawmaking ${ }^{46}$, has two sides. On the one hand, it does indeed follow from this premise that there is but one legislative solution in a legal text, which is discovered by those who apply the law ${ }^{47}$. On the other hand, however, two questions may be asked. The first one is whether consent to such an argument shouldn't prompt recognition that the complementary creative interpretation has no creative quality either, as a lawyer needs to have regard for the limitations resulting from the assumption of the legislator's rationality during any (and thus also this) interpretation. From this point of view, one may assert that examining what the lawmaker has decided is replaced here by examining what the lawmaker would have decided, if a proper regulation had been put in place. There is, after all, a certain element of counterfactualism in both these processes, since the point here is not to decode

42 M. Zieliński, Wyktadnia..., pp. 208-209.

43 M. Zieliński, Wyktadnia ..., p. 209.

44 M. Zieliński, Wykładnia..., p. 209.

45 See: S. Czepita, S. Wronkowska, M. Zieliński, Zatożenia szkoly..., pp. 5-8. It must be added, however, that this concept (and the entire Poznań-Szczecin school) has a complicated approach to legal positivism and representatives of this group themselves admit so. See: M. Zirk-Sadowski, Pozytywizm prawniczy a filozoficzna opozycja podmiotu i przedmiotu poznania [Eng. Legal Positivism and the Philosophical Opposition of the Subject and Object of Cognition], in: J. Stelmach (ed.), Studia..., passim.

46 M. Zieliński, Wyktadnia..., p. 209.

47 M. Zieliński, Wyktadnia..., p. 209. 
a message of a sociological lawmaker, but a rational one ${ }^{48}$. The risk of "subjective deviations from the actual content of the text (footnote, legislative act) ${ }^{49}$ incorporated therein by a lawmaker" after all concerns content which is a certain interpretative construct, yet this does not mean that the risk thus becomes less real or less risky. Using a handy distinction proposed by Bogucki, it can be said that ontologically law-making and at the same time methodologically reproductive actions occur on both the sides of the above-mentioned boundary ${ }^{50}$. Although most probably their intensity there is not the same, yet drawing any rigid delimitation line seems problematic.

The second and more important question concerns the status of this argument given Leszek Nowak's undisguised and well-known to theoreticians counterfactual quality of this assumption. Since it is not so much the belief that the real-life lawmaker is rational but the description how to (and, in the modified version, an imposed order how one must) interpret a legal text as if it was produced by a rational lawmaker, then the argument built around it does not so much favour the separation between the creative element of interpretation from the reproductive one, but in favour of distinguishing an arbitrary interpretation from an unarbitrary one. It seems, therefore, that the more theoretically and pragmatically legitimate way of legitimising the legal interpretation practice today might just be to signpost, in accordance with hermeneutics, the weakening of the boundary between the creative and reproductive elements of interpretation rather than to defend that boundary. Thus, the opposition between the creative and reproductive ceases to be clear-cut, and the key focus turns to a question whether interpretation is conducted in accordance with or in violation of the principles of the art of law, directed at the exegesis of the applicable legal text. Under this approach, the assumption of the lawmaker's rationality remains the key element in the self-understanding of the legal practice and, as pointed out by Artur Kozak, provides standards for the control of interpretation decisions ${ }^{51}$. However, these standards are not so much directly associated with the close adherence to the legal text as with dedication to the juristic way of thinking, where holding the text in high regard is very important. In this context, an accurate observation by Andrzej Bator is worth quoting:

All analytical theories of law, and in particular normative theories of interpretation, the derivative concept being one of them, strengthen the role of a lawyer in the actual distribution of power buried behind legal scholars' conceptual constructs, of which the assumption of lawmaker's rationality seems to be very rudimentary ${ }^{52}$.

And, a little further:

The assumption of lawmaker's rationality should not legitimise the law as a simple instrument in the hands of a single sociological lawmaker; quite the contrary, it should inspire actions on

48 M. Zieliński, Wyktadnia ..., p. 258-259.

49 M. Zieliński, Podstawowe zasady wspótczesnej wyktadni prawa [Eng. Basic Principles of Contemporary Legal Interpretation], in: P. Winczorek (ed.), Teoria i praktyka wyktadni prawa [Eng. Theory and Practice of Legal Interpretation], Warszawa 2005, p. 119; M. Zieliński, Wyznaczniki..., p. 11.

50 See: O. Bogucki, O sposobach pojmowania twórczego charakteru interpretacji [Eng. Methods of Understanding the Creative Nature of Interpretation], "Archiwum Filozofii Prawa i Filozofii Społecznej” 2013/1, pp. 21-25.

51 A. Kozak, Charakterystyka kategorii 'racjonalny prawodawca' w sqdowym stosowaniu prawa [Eng. Properties of the "Rational Legislator" Category in the Judicial Application of Law], in: M. Zirk-Sadowski (ed.), Filozoficzno-teoretyczne problemy squdowego stosowania prawa. XII Ogólnopolski Zjazd Katedr Teorii i Filozofii Prawa (Łódź, 8-10 listopada 1996 r.) [Philosophical and Theoretical Problems of Judicial Application of Law. XII National Meeting of Chairs of Theory and Philosophy of Law (Łódź, 8-10 November 1996)], Łódź, 1997, pp. 134-135.

52 A. Bator, $O$ adekwatności..., p. 26. 
the part of an interpreter who adapts the cognition of the text to the needs and expectations of the social context (domestic case, European case) in which the law is interpreted ${ }^{53}$.

Therefore, it would seem that the construct of a rational lawmaker does not so much provide an argument in favour of a strong separation between what is creative and what is not, but rather favours the discursive quality of the law. On the one hand, it gives the interpreter a "room for manoeuvre" and at the same time expands the degree of responsibility for the end-result of the interpretation process, while on the other hand, it provides framework for argumentation which is intersubjectively controllable. Thus, juristic culture becomes a factor that leads to the law gaining a partial autonomy from politics ${ }^{54}$. The sociological lawmaker now ceases to be the governor of the meaning of the law, all while remaining one of the key players. Inasmuch the power of creating a legal text is shared only - and shared it must be, if only for the duration of legislative acts in time and multicentricity of modern law - with other sociological lawmakers, yet it does not have any conclusive power over the meaning of the text.

It also seems that the sharp-cut separation of interpretation of the law from its co-creation is somewhat conflicting with the recognition, very apt in our view, of the derivative concept of the interpretation of the law as creating a room for the law-making role of the science of law and legal practice and, "furthermore, assuming the recognition of the most broadly understood interpretation (exegesis) of legal regulations as an act that is not purely cognitive, reproductive, but also creative in certain aspects" 55 . Let us observe that the correspondence of the foregoing with the above-mentioned manner of highlighting and setting the boundary for the law-making activity would require accepting that the said creative aspects are limited to a complementary creative interpretation only, i.e., to what we read would best be eliminated by introducing a fast-track legislative path $^{56}$. Meanwhile, in our view the theoretical sophistication of the derivative concept and its practical attractiveness lies, inter alia, in the fact that the element of creativity in decoding a legal text is not a marginal and essentially discardable element in this concept, but an important aspect of interpretation. It must be strongly emphasised that this element is not to be approached freely, but forms a part of a complicated game between a legal text and a broadly understood interpreter, while the derivative concept itself appears to resemble a detailed and systemic manual how to play this game.

In this context it is also worth noting that Ziembiński himself seems to be far from advocating strict separation of reproductive and creative interpretations. He draws attention to the importance of elements of law-applying process such as the presence of decisions that are not subject to algorithmisation, making evaluative choices or inconsistency of legal scholars' writings with the body of judgements ${ }^{57}$. As this theoretician wrote, the task of lawyers is to present "to the society and to the officials of the state apparatus" 58

\footnotetext{
3 A. Bator, O adekwatności..., p. 27.

54 See: W. Gromski, Autonomia prawa jako funkcja kultury prawnej [Eng. Autonomy of Law as a Function of Legal Culture], in: W. Gromski (ed.), Z zagadnień teorii i filozofii prawa. Autonomia prawa [Eng. Aspects of the Theory and Philosophy of Law: Autonomy of Law], Wrocław 2001.

55 S. Czepita, S. Wronkowska, M. Zieliński, Założenia szkoty..., p. 11.

M. Zieliński, Wyktadnia..., p. 209.

57 Z. Ziembiński, Wstęp do aksjologii dla prawników [Eng. Introduction to Axiology for Lawyers], Warszawa 1990, p. 161. See also: A. Kozak, Pojmowanie prawa w teorii wyktadni [Eng. Understanding Law in Theory of Interpretation], Wrocław 1997, p. 48-49.

58 Z. Ziembiński, Problemy podstawowe prawoznawstwa [Eng. Fundamental Problems of Jurisprudence], Warszawa 1980, p. 274.
} 
a system of legal norms as being coherent and compact, "even if the concepts of the actual participants of the law-making process were inconsistent, unclear and clearly failed to correspond to the expectations of rationality" ${ }^{59}$. Therefore, the task of juristic culture is what Jerzy Leszczyński presents as the positivization of the law $^{60}$. Let us recall that one of the aspects of this process is a partial blurring of the boundary between the interpretation of and co-creation of law. Ziembinski himself summarised his deliberations on the boundary between the application of law and its co-creation in the following way:

The category of actions that are attributed with a law-making quality has blurred boundaries. It would even be difficult to devise a regulating definition that would permit setting in a conventional way a strict scope for action of a law-making quality, and certain actions have this type of quality to a marginal extent only, as it seems ${ }^{61}$.

It should, however, be strongly emphasised that it would be a blunder to accept that this approach leads to the anarchism of interpretation and reducing the role of conduct conforming to the principles developed by the juristic culture, including the principles of interpretation adopted as part of it. Quite the opposite: weakening of the ontological status of the law amplifies the importance of existence and observance of rules of legal exegesis.

Leaving aside the issue of the law-making quality in interpretation, let us also mention that the adoption of a concept of interpretation which is based on the distinction between a legal provision and a legal norm carries a number of vital consequences not only of a theoretical, but also of a practical nature. For example, in the requirement laid down in Article 7 of the Constitution of the Republic of Poland ${ }^{62}$ that "[p]ublic authorities shall function on the basis of, and within the limits of, the law", the said "law" should be understood precisely as norms rather than legal provisions. Notwithstanding that in the statutory law system, norms are derived from legal provisions, yet not every component of a legal norm will always be directly reflected in a text of legal provisions. As it is emphasized in legal literature, this approach is extremely important for the building of arguments and the scope of admissible corrective dimension of legal interpretation ${ }^{63}$.

In addition to the properties of a legal text which are directly associated with the distinction between legal norms and legal provisions (such as the fragmentation and concentration of legal norms in legal provisions $)^{64}$, there are several other properties of a legal text which are covered under the derivative concept and which make it necessary for the text to be interpreted. These properties include, inter alia: variability, ambiguity, occurrence of undefined and imprecise phrases or, more generally, the basic openness of a legal text ${ }^{65}$. With the recognition of the last of the above-mentioned qualities, the derivative concept of interpretation has become more open to ethical aspects connected with interpretation ${ }^{66}$.

\footnotetext{
59 Z. Ziembiński, Problemy..., p. 274.

60 J. Leszczyński, Pozytywizacja prawa w dyskursie dogmatycznym [Eng. Positivization of Law in the Dogmatic Discourse], Kraków 2010.

61 Z. Ziembiński, Tworzenie..., p. 50.

62 The Constitution of the Republic of Poland of 2 April 1997 (Polish title: Konstytucja Rzeczypospolitej Polskiej z 2.04.1997 r., Dz. U. Nr 78, poz. 483 ze zm.).

63 See: M. Walasik, Analogia w prawie procesowym cywilnym [Eng. Analogy in Civil Procedural Law], Warszawa 2013, pp. 374-375.

64 M. Zieliński, Wyktadnia ..., p. 101-127.

65 Zob. M. Zieliński, Wyktadnia..., pp. 128-196.

66 Zob. M. Zieliński, M. Zirk-Sadowski, Klaryfikacyjność..., p. 110.
} 


\section{The interpretation process and reflectiveness}

The problem of the status of interpretation is one of those issues that continue to provoke discussion in Polish legal theory ${ }^{67}$. It is demonstrated by the debate around the clara non sunt interpretanda principle. Zieliński challenges this principle on three levels, respectively: 1) methodological, 2) empirical, and 3) ethical ${ }^{68}$. Many of the arguments raised on the said levels revolve around the idea that understanding of a legal text requires reflection $^{69}$. In this context, let us quote Zieliński's own words:

To this day, it is still not clear what direct understanding is supposed to mean (...). If, for example, it were to stand for an automatic, unreflective perception of the content of an expression, while interpretation, as well known, is no doubt a reflective process, then, according to the clara non sunt interpretanda principle, we would have to agree, as a consequence, that this thoughtless certainty as to the content of a certain phrase would be an uncrossable barrier, shielding the said phrase against extracting its meaning (even if it were the same meaning) in a reflective way ${ }^{70}$.

Understanding of a legal text can therefore be reflective or unreflective. The grounds for this distinction can be discovered in the cognitive process of the interpreter. As noted by Zieliński, the changeability of a legal text requires "vigilance and meticulousness on the part of the interpreter, both in connection with the modifications introduced as a result of the amendment as well as on account of the natural variability of meaning of individual words. Without a subtly reflective approach to understanding, it would be difficult to ensure that the understanding of the text is up-to-date" "71 If we decipher these words correctly, then at least two rationales for treatment of legal interpretation from the perspective of reflectiveness come into focus. The first rationale is associated with changeability of law. In this aspect, reflectiveness of interpretation is meant to facilitate our following changes in the law. Nonetheless, reflectiveness is not "exhausted" by changeability of the law alone. Thus, the second rationale is associated with the "natural mutability in the meaning of individual words". In this area, the purpose of interpretation is to open up the meaning of words to a systemic and functional context. All while directives of linguistic interpretation may be attributed to linguistic motives, principles of systematic and functional interpretation may be attributed to extralinguistic ones ${ }^{72}$.

Reflective interpretation therefore envisages taking into account different rationales and, in consequence, allowing for rivalry between arguments that can be construed based on linguistic and extralinguistic directives. It also provides for, when certain conditions are met, the potential departure from the meaning of concepts established based on previous rationales, in this case linguistic ones. This option is subject to certain

${ }_{67}$ M. Zieliński, M. Zirk-Sadowski, Klaryfikacyjność..., pp. 101-102.

68 M. Zieliński, Clara non sunt interpretanda - mity i rzeczywistość [Eng. Clara Non Sunt Interpretanda: Myths and Reality], "Zeszyty Naukowe Sądownictwa Administracyjnego" 2012/6, pp. 9-23. See also: A. Choduń, Aspekty językowe..., p. 96ff.; K. Płeszka, Wyktadnia ..., pp. 193-197.

69 M. Zieliński, Wyktadnia ..., p. 55. See also: A. Choduń, M. Zieliński, Aspekty granic wyktadni prawa [Eng. Aspects of the Limits of Legal Interpretation], in: W. Miemiec (ed.), Ksiega Jubileuszowa Profesora Ryszarda Mastalskiego. Stanowienie i stosowanie prawa podatkowego [Eng. Jubilee Book of Professor Ryszard Mastalski: Tax Law Legislation and Application], Wrocław 2009, pp. 86-87.

70 M. Zieliński, Podstawowe zasady..., p. 119.

71 M. Zieliński, Clara non sunt..., p. 14.

72 M. Zieliński, Wyktadnia..., p. 210. On three types of interpretation as contexts see: J. Leszczyński, Pozytywizacja..., p. $224 \mathrm{ff}$. 
conditions, of which the key one is connected to the assumption of the rationality of the lawmaker, particularly as regards the coherence of the adopted value system.

Two aspects are important for this kind of reflectiveness ${ }^{73}$. Firstly, it is the self-consciousness (Polish: samoświadomość) of a lawyer and the practice of interpretation. Secondly, it is self-direction (Polish: samozwrotność) understood as the ability to revise the assumed rationales or to problematise the recommended course of action ${ }^{74}$. The quality of legal interpretation depends not only on the jurist's attitude, but also on the culture of interpretation that recommends a specific action to be taken. This understanding of reflectivity also strengthens the thinking that the form of the juristic culture indeed does depend on the lawyers who create it. Let us now address both of the above mentioned features of reflectiveness (self-consciousness and self-direction) more broadly in the context of the derivative concept of legal interpretation.

\section{Reflectiveness as self-consciousness}

The derivative concept therefore favours the inclusion of linguistic, systemic and functional directives in the interpretation process ${ }^{75}$. In accordance with this concept, the directives of linguistic interpretation are fundamental and chronologically come first. Even so, this does not exclude those interpretative directives that relate to the systemic and functional context. What is more, under this concept, there is an aspect of interrelationship between individual rules.

As emphasized by Zieliński and Zirk-Sadowski, "[m]eaning is actually a game between the interpreter and the broadly understood text. Interpretation as a game means that there is no such thing as the so-called "correct" understanding of the text" 76 .

The concept of a game between a text and an interpreter is an argument in favour of modifying the analytical approach to the meaning of a legal text as described by Tomasz Spyra. To recapitulate, this Kraków-based researcher distinguishes two standard approaches to the meaning of a text ${ }^{77}$. Under the first of these, i.e., the analytical approach, it is presupposed that the meaning is present in the text itself, while the interpreter merely extracts it. The second approach takes the view that there is no such thing as a stabilised meaning of a text ready to be extracted, therefore, meaning is more accurately something that is co-created in the process of interpretation. This approach underscores non-autonomy of a legal text.

The endeavour to present the process of interpretation as a certain form of game involves an assumption of not only a specific position as regards the ontology of a legal text, but also juristic culture. In this light, let us quote after Zieliński and Zirk-Sadowski: "the adoption of the omnia sunt interpretanda principle (...) makes the lawyer conscious of also his or her specific existential position, and is not only a practical guide to interpretation"78. This position is a significant reason to recognize reflectiveness

73 See: M. Pichlak, Refleksyjność prawa. Od teorii społecznej do strategii regulacji i z powrotem [Eng. Reflectiveness of Law: From Social Theory to Strategy of Regulation and Back], Łódź 2019, particularly pp. 24-27.

74 Anthony Giddens states: "in the context of the post-traditional order of late-modern societies «the self becomes a reflexive project»”. A. Giddens, Nowoczesność i tożsamość. 'Ja' i spoteczeństwo w epoce późnej nowoczesności [Eng. Modernity and Self-Identity: Self and Society in the Late Modern Age], Warszawa 2010, p. 197.

75 M. Zieliński, Wyktadnia..., p. 210.

76 M. Zieliński, M. Zirk-Sadowski, Klaryfikacyjność..., p. 110.

77 T. Spyra, Granice wyktadni prawa. Znaczenie jęzkowe tekstu prawnego jako granica wyktadni [Eng. The Limits of Legal Interpretation. Linguistic Meaning of a Legal Text as the Limit for Interpretation], Kraków 2006, pp. 173-183.

78 M. Zieliński, M. Zirk-Sadowski, Klaryfikacyjność..., p. 110. 
not only in the individual aspect, but also as a category of juristic culture. In order to maintain lawyers' self-consciousness at the institutional level, shaping the subjectivity of the performer of this role on an intersubjective factor (e.g. juristic culture) and individual factor (individual morality) becomes of key importance. Considering this dualism, there emerges an image of a lawyer that can be sketched using the category of Jean-Claude Kaufmann's double helix ${ }^{79}$. According to it, the identity of an individual can be presented using two modalities: the social habitus and individualisation. The first modality highlights the institutional dimension of identity. It accentuates that performance of a role and the process of interpretation is not a free act, but an expression of communicative competence acquired through education. On the other hand, the second modality lays emphasis on the importance of subjectivity and individuality in the process of formation of individual's identity. Here, the reflective attitude involves self-consciousness maintained by a lawyer as a member of interpretive community. The extent to which this attitude is individualistic in nature and where it stems from what is required by the interpretive community depends on the juristic culture. For this reason, the relationship between a lawyer and the juristic culture can be presented as a relation of complementation. According to it, culture influences identity of lawyers, all while the subjectivity of the interpreter and the manner of his or her action contributes to the form of the juristic culture. Neither the subjectivity of the interpreter nor the specificity of the juristic culture vanishes in this relationship.

In this perspective, the self-consciousness of a lawyer and the interpretative community becomes one of the limits of interpretation that affects the way a legal text is comprehended ${ }^{80}$. As pointed out by Choduń, in the derivative concept of interpretation, the attitude of the interpreter is not reproductive, since ' $[\mathrm{t}] \mathrm{he}$ interpreter does not discover meanings, but establishes them, if only because he or she selects the meaning, and not only in circumstances of lexical ambiguity. It is not, however, a subjective choice at his or her own discretion" ${ }^{81}$.

\section{Reflectiveness as revisability}

Reflectiveness understood as self-consciousness implies also a potential revisability of use of legal interpretation directives. The objective of challenging the result of a linguistic interpretation is to prevent bad law in a technical and axiological sense and is possible under the derivative concept of legal interpretation.

The first of these aspects was highlighted by Zieliński who emphasized the adjustive function of interpretation, as well as its complementary creative role ${ }^{82}$. The reasons for this role to be brought into play are editorial errors of a legal text and legislative shortcomings ${ }^{83}$.

The second of these cases may refer to a situation of conflict between individual rationales. Such a situation, as emphasised by Zieliński, "can prima facie be theoretically

\footnotetext{
79 J.-C. Kaufmann, Kiedy Ja jest innym. Dlaczego i jak coś się w nas zmienia [Fr. Quand Je est un autre: Pourquoi et comment ça change en nous], Warszawa 2013, p. 122ff. See also: P. Kaczmarek, Dystans do roli w zawodzie prawnika [Eng. Distance to the Lawyer's Role], Warszawa 2019, p. 105.

80 See: A. Chodun, M. Zieliński, Aspekty granic..., p. 91.

81 A. Chodun, Aspekty językowe..., p. 34.

82 M. Zieliński, Wyktadnia..., p. 206-209.

83 M. Zieliński, Wyktadnia..., pp. 206, 208. See also: M. Smolak, Wyktadnia celowościowa z perspektywy pragmatycznej [Eng. Purpose-Oriented Interpretation from a Pragmatic Perspective], Warszawa 2012, pp. 57-58.
} 
solved in two ways, i.e., either the result of the functional interpretation or the result of the linguistic interpretation is rejected"84. However, in this context Zieliński identifies a growing significance of a third, intermediate solution: "if, in the case of conflicting results of functional and linguistic interpretation, it turns out that the result obtained based on linguistic directives disrupts the fundamental axiological assumptions of the lawmaker (especially its system of values), then the result obtained based on the application of functional rules should be given precedence" 85 . This solution therefore puts forward premises that justify overruling the linguistic interpretation. This approach differs from the other two in that it deals with an aspect of the reference to the directives of interpretation which requires that the individual rationales be weighed against each other.

Linguistic interpretation can be overruled in a weak or strong way ${ }^{86}$. The first of the two cases occurs when a linguistic interpretation brings different viable solutions to light. In such a situation, functional interpretation "serves the purpose of choosing one of them as the right one" 87 . The second case is a solution where priority is given to a result that has been established based on functional interpretation directives. These two overruling approaches can be correlated with two types of rationales that have the nature of, respectively, optimisation and guarantee, as discussed by Bogucki ${ }^{8}$. The optimisation rationale occurs when the objective of functional interpretation is to select the best solution out of those available at the linguistic level. The guarantee rationale in turn is when the objective of functional interpretation is to prevent acceptance of the result of a linguistic interpretation, which we can describe as axiologically bad ${ }^{89}$.

The problem of revising the result produced by the application of the linguistic interpretation is described by the rules of interpretation proposed by Zieliński:

DIRECTIVE 39: If the linguistic meaning disrupts certain values, the following should be done:

1) the values in question should be identified;

2) it should be specified how they are deemed to be fundamental (irrebuttable).

DIRECTIVE 40: Where the linguistic meaning disrupts these identified irrebuttable values, the linguistically clear meaning of the phrase to be interpreted should be altered in such a way as to ensure axiological consistency (broadening or narrowing interpretation) ${ }^{90}$.

Overruling an argument developed based on linguistic rules in favour of extratextual argumentation reveals an important aspect of causal quality of interpretation as well as the interplay between various factors that influence the interpretation of law ${ }^{91}$. In this respect, we have a complex relationship between various rationales of action. The sequence of the reasons within the derivative concept is not incidental ${ }^{92}$. The topogra-

${ }_{84}$ M. Zieliński, Wyktadnia ..., p. 212.

85 M. Zieliński, Wyktadnia..., p. 212.

86 See: O. Bogucki, Model wyktadni funkcjonalnej w derywacyjnej koncepcji wyktadni prawa [Eng. Model of Functional Interpretation in a Derivative Concept of Legal Interpretation], Szczecin 2016, p. 48ff and 248ff. Potential solutions in case of interpretative conflicts are discussed by: L. Leszczyński, Zagadnienia teorii stosowania prawa. Doktryna i tezy orzecznictwa [Eng. Aspects of Law Application Theory. Doctrine and Case Law Theses], Kraków 2001, p. 142-144.

87 O. Bogucki, Model..., p. 48. See also: Z. Ziembiński, Wstęp..., p. 185.

88 O. Bogucki, Model..., p. 249.

89 See: M. Zieliński, Wyktadnia ..., pp. 212, 216.

$90 \quad$ M. Zieliński, Wyktadnia ..., pp. 301-302.

91 M. Zieliński, Wyktadnia..., p. 208.

92 M. Zieliński, Wyktadnia..., p. 210. 
phy of the rules of interpretation (linguistic, systemic and functional) that emerges from the concept in question determines the recommended direction of lawyer's actions, but at the same time enables overriding the linguistic meaning. Let us mention at this point that Zieliński distinguishes two circumstances of overruling the linguistic meaning of a legal text ${ }^{93}$. The first of the two involves the perspective of what we refer to as the juristic culture and, in this respect, the key function is played by the directives of functional interpretation. The second of these circumstances, on the other hand, occurs when the grounds for the revision lie in the legal system. These findings confirm that the derivative concept of legal interpretation envisages a potential revision of meaning construed based on previous rationales.

The issue of revising the rules of interpretation, in reference to the derivative concept, is discussed by Jerzy Leszczyński. According to this Łódź-based theoretician, when making a systemic and functional interpretation, the interpreter "sort of methodically matches meanings with external circumstances" ${ }^{\prime 4}$. The external context on top of the linguistic meaning of concepts is provided by the legal system (systemic interpretation) and the juristic culture (functional interpretation). Revision of linguistic meaning based on functional interpretation is also presented by Marek Smolak who noted that the functional context can be considered more broadly, going beyond the aspect of the juristic culture ${ }^{95}$. Considering the findings of this Poznań-based legal philosopher, the factors comprising politico-legal culture can also be established within the functional context ${ }^{96}$. Both these theoreticians thus put emphasis on the openness of the legal text to other factors. This finding strengthens the line of argumentation in favour of presentation of the process of interpretation as a game between a legal text and an interpreter, in which choices falling within the frame of juristic culture and politico-legal culture play an important role.

\section{Final remarks}

The task we took on in this paper was to examine the derivative concept of legal interpretation from the perspective of the construct of the limits of juristic power. In this context, we were encouraged by the important words of Zieliński and Zirk-Sadowski, according to whom interpretation is a kind of game between the text and the interpreter. We strived to study the derivative concept as a universal set of instructions for this complex game, in which extratextual factors add to the text with varying intensity and in many different ways. An additional stimulus for us was the declared openness of the derivative concept and its explicitly confirmed compatibility with the hermeneutical tradition of thinking about interpretation.

By way of recapitulation, we would like to bring out the key findings, as outlined below.

Firstly, in the derivative model, the legal text provides the basic reference for establishing the content of the law, without, however, fully determining it. In other words,

93 M. Zieliński, Wyktadnia..., p. 217.

94 J. Leszczyński, Pozytywizacja ..., p. 227.

95 M. Smolak, Uzasadnienie decyzji interpretacyjnej jako praktyczne rozumowanie prawnicze [Eng. Reasons for Interpretative Decision as Practical Legal Reasoning], in: A. Choduń, S. Czepita (eds.), W poszukiwaniu..., p. 152.

96 On the role of open axiology in the process of interpretation of law: L. Leszczyński, Wyktadnia prawa ..., p. $60 \mathrm{ff}$. 
the text is an important, but not the only, determinant of how an interpreter should reconstruct the law.

Secondly, it seems that in this concept of interpretation we can find, on the one hand, a significant degree of confirmation and detailing of what has been described above as the relationship of adjustment and, on the other hand, a modification of what functions as a relationship of complementation within the structure of limits. Nonetheless, the unilateral direction of this relationship, assumed by us, becomes somewhat problematic. Although it may be inferred that a sequential application of the directives of interpretation combined with the primacy of linguistic rules over extralinguistic ones partially confirm the general relevance of this direction, yet a closer look at the derivative model leads to the conclusion that this relationship is much more complex. Specifically, it seems that reference to the politico-legal culture is important not only for the exceptionally acceptable overruling of the semantic meaning of the text (therefore, in the context of the relationship of adjustment), but also for a more standard process of determining the content of the law, i.e., adding meaning derived from an extralinguistic context to the semantics of the text, but within the limits set by that semantics (relationship of complementation). In brief, the relationship of complementarity, though it often follows the direction we have specified, can also take a different form, i.e., a mutual complementation of at least some limits.

Thirdly, the derivative concept of interpretation reveals the importance of reflectiveness in the process of interpretation, and thus also the role played in it by the approach adopted by the interpreter. The quality of legal norms construed from legal provisions thus depends not only on the provisions as well as tools and modes of action developed by the juristic culture, but also on the attitude of individual participants in that culture, their reflectiveness and the associated axiological perception.

Further questions and uncertainties arise against the background of the above findings, which we merely mention here. The first of these questions is connected with the second of the abovementioned conclusions. Perhaps the exception referred to there is caused not so much by a reversal of the direction of complementation, but an even more elementary reason. In the derivative concept of interpretation not only is there no breakdown of a cultural factor into a politico-juristic culture and a juristic culture, as we have assumed, but - the derivative concept of legal interpretation being a model with analytical roots - the cultural factor itself is also thematized differently, with the concept of a rational legislator playing a fundamental role in this context. Thus, the derivative model invokes a question whether the breakdown of the cultural element into a political and legal, as we have adopted, is at all justified.

The second issue concerns the figure of reflectivity, as mentioned in the third proposal. Perhaps it should also be extended to other levels of the structure of limits. It is not only a lawyer who can be reflective or unreflective, but also, as we have tried to indicate, the juristic culture as a whole and the legislator who creates a legal text. In the positive scenario, when reflection can be triggered, there is a mutual optimisation of the results of actions taking place within the individual limits, and sometimes an optimisation of the limits themselves (that is, improving the quality of juristic culture through an individual contribution of jurists). In the negative scenario, it is just the opposite. 


\title{
On an Interpreter's Game with the Legal Text and Extratextual Factors in the Derivative Concept of Legal Interpretation
}

\begin{abstract}
The aim of this paper is to show the derivative concept of legal interpretation from the point of view of the structure of limits of the juristic power. This structure includes the politico-legal culture, the legal text, the juristic culture, and personal factors, such as ethical and aesthetic judgements.

These days, the derivative concept is the most influential Polish theory of legal interpretation. According to this concept the process of interpreting the law is a kind of a game between the legal text and extratextual factors, which are treated as extratextual limits of juristic power. On the one hand, the legal text does not determine the full meaning of the law, although it greatly contributes to it. On the other hand, the derivative concept precisely identifies certain others factors that are relevant for the content of law.
\end{abstract}

Keywords: derivative concept of legal interpretation, limits of juristic power, legal text

Polish version of the paper was published in print as: P. Jabtonski, P. Kaczmarek, O grze interpretatora $z$ tekstem prawnym i czynnikami pozatekstowymi $w$ derywacyjnej koncepcji wyktadni prawa, "Archiwum Filozofii Prawa i Filozofii Spotecznej” 2020/2, pp. 49-65. The English translation was proofread by Joanna Miler-Cassino. Proofreading was financed through the Polish Ministry of Science and Higher Education programme "Aid for journals" (Polish: "Wsparcie dla czasopism"), contract no. 211/WCN/2019/1 of 22 July 2019. The English translation has not been published in print. 


\section{BIBLIOGRAFIA / REFERENCES:}

Bator, A. (2015). O adekwatności założeń derywacyjnej koncepcji wykładni do badań nad interpretacją prawa Unii Europejskiej. Studia Prawa Publicznego 2/10, 11-34.

Bogucki, O. (2016). Model wyktadni funkcjonalnej $w$ derywacyjnej koncepcji wyktadni prawa. Szczecin: Polgres.

Bogucki, O. (2013). O sposobach pojmowania twórczego charakteru interpretacji. Archiwum Filozofii Prawa i Filozofii Spolecznej 1/6, 21-33.

Choduń, A. (2018). Aspekty językowe derywacyjnej koncepcji wyktadni prawa. Szczecin: Wydawnictwo Naukowe Uniwersytetu Szczecińskiego.

Choduń, A., Zieliński, M. (2009). Aspekty granic wykładni prawa. In W. Miemiec (Ed.), Księga Jubileuszowa Profesora Ryszarda Mastalskiego. Stanowienie i stosowanie prawa podatkowego. Wrocław: Oficyna Wydawnicza Unimex.

Czepita, S., Wronkowska, S., Zieliński, M. (2013). Założenia szkoły poznańsko-szczecińskiej w teorii prawa. Państwo i Prawo 2/68, 3-16.

Giddens, A. (2010). Nowoczesność i tożsamość. „Ja” i spoleczeństwo w epoce późnej nowoczesności. Warszawa: Wydawnictwo Naukowe PWN.

Gizbert-Studnicki, T. (2010). Dyrektywy wykładni drugiego stopnia. In A. Choduń, S. Czepita (Eds.), $W$ poszukiwaniu dobra wspólnego. Księga jubileuszowa Profesora Macieja Zielińskiego. Szczecin: Wydawnictwo Naukowe Uniwersytetu Szczecińskiego.

Gizbert-Studnicki, T. (2003). Rozkład ciężaru argumentacji w dyskursie interpretacyjnym. In J. Stelmach (Ed.), Studia z filozofii prawa. Kraków: Wydawnictwo Uniwersytetu Jagiellońskiego.

Gizbert-Studnicki, T. (1985). Wykładnia celowościowa. Studia Prawnicze 85-86, 51-70.

Godek, A. (2011). Czy koniec teorii wykładni prawa? Kilka uwag o możliwych rozwinięciach derywacyjnej koncepcji wykładni Macieja Zielińskiego na wykładnię prawa $\mathrm{w}$ sferze postakcesyjnej z wewnętrznej perspektywy interpretacyjnej. In P. Jabłoński (Ed.), Czy koniec teorii prawa? Z zagadnień teorii i filozofii prawa, numer monograficzny Acta Universitatis Wratislaviensis, No. 3337, seria Prawo, CCCXII. Wrocław: Wydawnictwo Uniwersytetu Wrocławskiego.

Gromski, W. (2011). Autonomia prawa jako funkcja kultury prawnej. In W. Gromski (Ed.), Zzagadnień teorii i filozofii prawa. Autonomia prawa. Wrocław: Kolonia Limited.

Jabłoński, P., Kaczmarek, P. (2017). Granice władzy prawniczej w perspektywie polskiej tradycji socjologicznej. Kraków: Wydawnictwo NOMOS.

Kaczmarek, P. (2019). Dystans do roli w zawodzie prawnika. Warszawa: Wydawnictwo C.H. Beck.

Kaufmann, J.-C. (2013). Kiedy Ja jest innym. Dlaczego i jak coś się w nas zmienia. Warszawa: Oficyna Naukowa.

Kozak, A. (1997). Charakterystyka kategorii „racjonalny prawodawca” w sądowym stosowaniu prawa. In M. Zirk-Sadowski (Ed.), Filozoficzno-teoretyczne problemy sadowego stosowania prawa. XII Ogólnopolski Zjazd Katedr Teorii i Filozofii Prawa (Łódź, 8-10 listopada 1996 r.). Łódź: Wydawnictwo Uniwersytetu Łódzkiego. 
Kozak, A. (1997). Pojmowanie prawa w teorii wykładni. Wrocław: Wydawnictwo Uniwersytetu Wrocławskiego.

Leszczyński, J. (2010). Pozytywizacja prawa $w$ dyskursie dogmatycznym. Kraków: Towarzystwo Autorów i Wydawców Prac Naukowych Universitas.

Leszczyński, L. (2009). Wykładnia operatywna (podstawowe właściwości). Państwo i Prawo 6, 11-23.

Kalisz, A., Leszczyński, L., Liżewski, B. (2011). Wykładnia prawa. Model ogólny a perspektywa Europejskiej Konwencji Praw Człowieka i prawa Unii Europejskiej. Lublin: Wydawnictwo Uniwersytetu Marii Curie-Skłodowskiej.

Leszczyński, L. (2001). Zagadnienia teorii stosowania prawa. Doktryna i tezy orzecznictwa. Kraków: Kantor Wydawniczy Zakamycze.

Matczak, M. (2010). Dwupoziomowość języka prawnego w derywacyjnej koncepcji wykładni i jej znaczenie dla współczesnych sporów w anglosaskiej interpretacji prawniczej. In A. Choduń, S. Czepita (Eds.), W poszukiwaniu dobra wspólnego. Księga jubileuszowa Profesora Macieja Zielińskiego. Szczecin: Wydawnictwo Naukowe Uniwersytetu Szczecińskiego.

Matczak, M. (2019). Imperium tekstu. Prawo jako postulowanie i urzeczywistnianie świata możliwego. Warszawa: Wydawnictwo Scholar.

Nowak, L. (1999). Zygmunta Ziembińskiego koncepcja interpretacji. Pewne komentarze, dopełnienia i aplikacje. In A. Klawitera, L. Nowak, P. Przybysz (Eds.), Umysł a rzeczywistość. Poznań: Zysk i s-ka.

Pichlak, M. (2019). Refleksyjność prawa. Od teorii spotecznej do strategii regulacji i z powrotem. Łódź: Wydawnictwo Uniwersytetu Łódzkiego.

Pietrzykowski, T. (2017). Naturalizm i granice nauk prawnych. Esej z metodologii prawoznawstwa. Warszawa: Wolters Kluwer.

Płeszka, K., Gizbert-Studnicki, T. (1984). Dwa ujęcia wykładni prawa. Próba konfrontacji. Zeszyty Naukowe Uniwersytetu Jagiellońskiego, Prace z nauk politycznych 20, 17-27.

Płeszka, K. (2010). Wyktadnia rozszerzająca. Kraków: Wolters Kluwer Polska.

Podgórecki, A. (2016). Mega-sociology. Warszawa: Instytut Profilaktyki Społecznej i Resocjalizacji UW.

Safjan, M. (2010). Uniwersalizacja wykładni prawa. In A. Choduń, S. Czepita (Eds.), W poszukiwaniu dobra wspólnego. Księga jubileuszowa Profesora Macieja Zielińskiego. Szczecin: Wydawnictwo Naukowe Uniwersytetu Szczecińskiego.

Sarkowicz, R. (2005). Uwagi o współczesnej interpretacji prawniczej. In S. Wronkowska (Ed.), Polska kultura prawna a proces integracji europejskiej. Kraków: Kantor Wydawniczy Zakamycze.

Smolak, M. (2010). Uzasadnienie decyzji interpretacyjnej jako praktyczne rozumowanie prawnicze. In A. Choduń, S. Czepita (Eds.), W poszukiwaniu dobra wspólnego. Księga jubileuszowa Profesora Macieja Zielińskiego. Szczecin: Wydawnictwo Naukowe Uniwersytetu Szczecińskiego.

Smolak, M. (2012). Wyktadnia celowościowa z perspektywy pragmatycznej. Warszawa: Wolters Kluwer Polska.

Spyra, T. (2006). Granice wyktadni prawa. Znaczenie językowe tekstu prawnego jako granica wyktadni. Kraków: Kantor Wydawniczy Zakamycze. 
Walasik, M. (2013). Analogia w prawie procesowym cywilnym. Warszawa: LexisNexis.

Zieliński, M., Bogucki, O., Choduń, A., Czepita, S., Kanarek, B., Municzewski, A. (2009). Zintegrowanie polskich koncepcji wykładni prawa. Ruch Prawniczy, Ekonomiczny $i$ Socjologiczny 2009/4, 23-39.

Zieliński, M. (2012). Clara non sunt interpretanda - mity i rzeczywistość. Zeszyty Naukowe Sadownictwa Administracyjnego 2012/6, 9-23.

Zieliński, M. (2006). Derywacyjna koncepcja wykładni jako koncepcja zintegrowana. Ruch Prawniczy, Ekonomiczny i Socjologiczny 2006/3, 93-101.

Zieliński, M. (1972). Interpretacja jako proces dekodowania tekstu prawnego. Poznań: Wydawnictwo Naukowe Uniwersytetu im. Adama Mickiewicza w Poznaniu.

Zieliński, M. (2011). Mitów w myśleniu o wykładni prawa ciąg dalszy. In A. Mróz, A. Niewiadomski, M. Pawelec (Eds.), Prawo - język - media. Warszawa: Międzywydziałowe Koło Naukowe Kultury Języka Prawnego i Prawniczego Lingua Iuris.

Zieliński, M. (2005). Podstawowe zasady współczesnej wykładni prawa. In P. Winczorek (Ed.), Teoria i praktyka wyktadni prawa. Warszawa: Wydawnictwo Liber.

Zieliński, M. (2017). Wykładnia prawa. Zasady - reguly-wskazówki. Warszawa: Wolters Kluwer Polska.

Zieliński, M. (1998). Wyznaczniki reguł wykładni prawa. Ruch Prawniczy Ekonomiczny i Socjologiczny 3-4/LX, 1-20.

Zieliński, M., Zirk-Sadowski, M. (2011). Klaryfikacyjność i derywacyjność w integrowaniu polskich teorii wykładni prawa. Ruch Prawniczy, Ekonomiczny i Socjologiczny 2/LXXIII, 99-111.

Ziembiński, Z. (1980). Problemy podstawowe prawoznawstwa. Warszawa: Państwowe Wydawnictwo Naukowe.

Ziembiński, Z. (1960). Przepis prawny i norma prawna. Ruch Prawniczy Ekonomiczny i Socjologiczny, $1 / 22,105-122$.

Ziembiński, Z. (1990). Wstęp do aksjologii dla prawników. Warszawa: Wydawnictwo Prawnicze.

Ziembiński, Z. (1993). Tworzenie a stanowienie i stosowanie prawa. Ruch Prawniczy, Ekonomiczny i Socjologiczny 4, 43-50.

Zirk-Sadowski, M. (2001). Pozytywizm prawniczy a filozoficzna opozycja podmiotu i przedmiotu poznania. In J. Stelmach (Ed.), Studia z filozofii prawa. Kraków: Wydawnictwo Uniwersytetu Jagiellońskiego. 